\title{
Levels of some heavy Metals in Cocoyam (Colocasia esculentum) grown on Soil receiving Effluent from a Paint Industry
}

\author{
${ }^{1}$ UDOSEN, ED; ${ }^{2}$ AKPAN, EO; ${ }^{3}$ SAM, SM. \\ Dept. of Chemistry, University of Uyo, Akwa Ibom State, Nigeria \\ ${ }^{3}$ Dept. of Plant Science and Biotechnology \\ University of Port Harcourt, Nigeria.
}

\begin{abstract}
The levels of some heavy metals in soil samples and tubers of cocoyam (Colocasia esculentum) grown on soil receiving paint wastes (PWS) has been investigated using Atomic Absorption spectrophotometer (Unicam 939/959 model). Similar analyses were carried out for the same plant from a control area. The studies revealed that although the P.W.S contained abnormally high levels of $\mathrm{Pb}\left(474.14 \mathrm{mgkg}^{-1}\right)$ and $\mathrm{Cu}\left(137.85 \mathrm{mgkg}^{-1}\right)$. The paint waste tuber (PWT) recorded low levels of these metals: $\mathrm{Pb}\left(2.13 \mathrm{mgkg}^{-1}\right)$ and $\mathrm{Cu}$ $\left(13.85 \mathrm{mgkg}^{-1}\right)$ respectively. Correlation analysis tested at 0.05 level of significance show that no significant correlation existed between the metals levels in the soil and the level in the tuber. In all cases the levels of the metals in the tubers were well below the upper limit documented for unpolluted plant. The results however suggest the ineffectiveness of the use of Colocasia esculentum as a bioindicator for heavy metal pollution in soil. ( ) JASEM

http://dx.doi.org/10.4314/jasem.v20i1.26
\end{abstract}

\section{Introduction}

Research has shown that heavy metals are present in all sludges and will accumulate in soil time. Greenland and Hayes (1981) maintain that heavy metals content of sludge depend to a large extent on the nature of the local industry and on the proportion of domestic wastes. Naidu et al (2003) reported that laboratory studies consistently demonstrate that the capacity of plant to bioaccumulate metals varies extensively with the nature of metals as well as with plant types. Studies by Food and Fertilizer Technology Centre (F.F.T.C) (2000) show a significant correlation between the concentration of heavy metals in plants and the concentration in the soil solution. Udosen (1994) after determining the level of heavy metals in Telfairia occidentalis from paint industry environment, reported marked difference in the degree of accumulation of zinc, lead, cadmium, copper and chromium in the plant samples from soil receiving paint wastes. According to Greenland and Hayes (1981), studies abound which show that difference do exist in the level of accumulation of heavy metals in the different parts of plant.

The study areas were: (i) a paint industry discharge farm where farming activities was ongoing and (ii) a site about $10 \mathrm{~km}$ west of the paint factory which serves as a background site. Cocoyam is a food grown for its starch rich corm (tuber). This cheap root crop is well relished by native of southern Nigeria. The fact that this plant thrived well in the effluent discharge farm raised the suspicion that the plant can bioaccumulate heavy metals from the soil to a level Correspondence authoremail: Eosamviek@yahoo.com that might prove harmful to human beings who eventually feed on this plant. Jones et al. (1986) maintain that heavy metals are known to be perhaps the most common of all the metabolic poisons. According to Hughes and Poole (1995), the heavy metals cation binds strongly to many ligands particularly soft ligands such as thiols in enzymes systems. The cations therefore exert toxic effects in several ways for example by displacing essential metals from their normal binding sites or by binding to proteins and nucleic acid thus altering their conformations. This work is therefore an attempt to investigate the extent to which cocoyam grown on the effluent discharge farm of the paint industry may accumulate heavy metals

\section{MATERIALS AND METHODS}

The sampling sites were divided into small grids of dimension $10 \mathrm{~m} \times 5 \mathrm{~m}$ each. Ten of such grids were obtained in each site. Plant samples and the corresponding soil samples were taken from each grid. Plant samples were carefully uprooted with the help of a stainless knife. The corresponding soil samples were collected at a depth of $0-15 \mathrm{~cm}$ using soil auger. Soil samples so collected were stored in black polythene bags and labeled as grid 1-10 as applicable to both the industrial and background soil respectively. The soil samples were dried for 48 hours. During this time samples were well separated to avoid cross contamination. Each sample was ground and homogenized. Thereafter the samples were sieved using a $2 \mathrm{~mm}$ sieve. Each of the samples was separately treated as follows: $2.0 \mathrm{~g}$ of the sieved 
sample in each case was put into a $100 \mathrm{~cm}^{3}$ beaker. $15 \mathrm{~cm}^{3}$ of an acid mixture (concentrated $\mathrm{HNO}_{3}$ and concentrated $\mathrm{HCIO}_{4}$ in the ratio 2:1 respectively) was added to the sample. The beaker was covered with watch glass. The beaker with its content was placed in a flume cupboard and heated to near dryness. On cooling, the mixture was leached with $20 \% \mathrm{HNO}_{3}$ and filtered with acid washed filter paper. The filtrate was diluted to $20 \mathrm{~cm}^{3}$ with distilled water. All samples were treated as described above. The resultant solutions were stored in plastic reagent bottles for heavy metal analyses.

The tubers on the other hand were thoroughly washed and peeled, free from extraneous materials. They were then chopped into smaller pieces and oven dried at $50-60^{\circ} \mathrm{C}$. After drying, the samples were ground into powder. $1.0 \mathrm{~g}$ of the ground sample in each case was put in a crucible and ashed in a furnace at a temperature $500-700^{\circ} \mathrm{C}$ for 4 hours. After cooling the ash, it was leached with $5 \mathrm{~cm}^{3}$ of 6 MHCI and transferred to $20 \mathrm{~cm}^{3}$ conical flask; the volume was made up to $20 \mathrm{~cm}^{3}$ with distilled water. The solutions were stored in plastic reagent bottles for heavy metal analysis. The solution for, the blank determination was treated in a similar manner but omitting the sample (Radojevic and Viadimir, 1999).

Total metal concentrations in the solution of plants and soil samples obtained as described above were determined using the procedures of Martin and Whitefield (1983) using Atomic absorption Spectrophotometer (AAS) (Unicam 939/959 model) the heavy metals analyzed for their total concentrations in sample solution were: $\mathrm{Cd}, \mathrm{Cu}, \mathrm{Fe}$, $\mathrm{Ni}, \mathrm{Pb}$ and $\mathrm{V}$.

\section{RESULTS AND DISCUSSION}

The mean concentration of the metals in the paint waste soil (PWS), background soil (BGS), paint waste tuber (PWT) and background tuber (BGT) is presented in table (1). For in-depth studies, the results of t-test analysis for statistical significance of the difference between mean concentrations of the heavy metal in the two sites is presented in table (2), while table (3) presents the linear correlation coefficient for metal concentration in paint waste soil and paint waste tuber.

Table 1: The *mean concentration of Metals in paint waste soil (PWS), paint waste tuber (PWT), background soil (BGS) and background tuber (BGT)

\begin{tabular}{lllcc}
\hline $\begin{array}{l}\text { Metal } \\
\left(\mathbf{m g k g}^{-1}\right)\end{array}$ & \multicolumn{4}{c}{ Variable } \\
\hline & \multicolumn{1}{c}{ PWS } & BGS & PWT & BGT \\
Fe & $143.38 \pm 1.88$ & $143.42 \pm 0.24$ & $102.04 \pm 18.98$ & $158.12 \pm 9.97$ \\
$\mathbf{N i}$ & $7.30 \pm 0.32$ & $4.82 \pm 0.26$ & $0.80 \pm 0.11$ & $2.67 \pm 0.16$ \\
$\mathbf{V}$ & $4.18 \pm 0.12$ & $2.41 \pm 0.11$ & $0.39 \pm 0.09$ & $1.83 \pm 0.09$ \\
$\mathbf{P b}$ & $474.14 \pm 21.03$ & $4.29 \pm 4.21$ & $2.13 \pm 0.78$ & $0.24 \pm 0.08$ \\
$\mathbf{C d}$ & $0.51 \pm 0.06$ & $1.16 \pm 0.06$ & $0.02 \pm 0.02$ & $1.60 \pm 0.07$ \\
$\mathbf{C u}$ & $137.85 \pm 12.52$ & $13.74 \pm 0.58$ & $11.34 \pm 1.68$ & $13.85 \pm 2.11$ \\
\hline
\end{tabular}

*Mean concentration in grid 1 to 10 .

Table 2: T-test analysis for statistical significance between the mean concentration for metals in samples from paint waste site and background site

\begin{tabular}{llll}
\hline Pair & $\mathrm{t}-$ & $\mathrm{t}-$ & Decision \\
& calculated & at \\
critical & $\mathrm{P}=0.05$ \\
\hline $\mathrm{Fe}$ in PWS $-\mathrm{Fe}$ in & 0.02 & 2.10 & \\
$\mathrm{BGS}$ & & $* *$ \\
$\mathrm{Fe}$ in PWT $-\mathrm{Fe}$ in & 2.26 & \\
$\mathrm{BGT}$ & & $*$ \\
$\mathrm{Ni}$ in PWS $-\mathrm{Ni}$ in & 6.38 & \\
$\mathrm{BGS}$ & & $* *$ \\
$\mathrm{Ni}$ in PWT $-\mathrm{Ni}$ in & 9.25 & & \\
\hline
\end{tabular}




\begin{tabular}{l}
\hline $\mathrm{BGT}$ \\
$\mathrm{V}$ in $\mathrm{PWS}-\mathrm{V}$ in 16.47 \\
$\mathrm{BGS}$ \\
$\mathrm{V}$ in $\mathrm{PWT}-\mathrm{V}$ in 12.57 \\
$\mathrm{BGT}$ \\
$\mathrm{Pb}$ in PWS $-\mathrm{Pb}$ in 22.41 \\
$\mathrm{BGS}$ \\
$\mathrm{Pb}$ in PWT $-\mathrm{Pb}$ in 2.46 \\
$\mathrm{BGT}$ \\
$\mathrm{Cd}$ in $\mathrm{PWS}-\mathrm{Cd}$ in 13.71 \\
$\mathrm{BGS}$ \\
$\mathrm{Cd}$ in PWT $-\mathrm{Cd}$ in 24.70 \\
$\mathrm{BGT}$ \\
$\mathrm{Cu}$ in PWS $-\mathrm{Cu}$ in 9.90 \\
$\mathrm{BGS}$ \\
$\mathrm{Cu}$ in PWT $-\mathrm{Cu}$ in 1.27 \\
$\mathrm{BGT}$
\end{tabular}

Table 3: Linear correlation coefficient for metal concentrations in paint waste soil (PWS) and paint waste tuber (PWT)

\begin{tabular}{lll}
\hline Metal & $\mathbf{r}$ & $\begin{array}{l}\text { Decision } \\
\text { at }\end{array}$ \\
\hline $\mathbf{F e}$ & 0.038 & $*$ \\
$\mathbf{N i}$ & -0.010 & $*$ \\
$\mathbf{V}$ & 0.428 & $*$ \\
$\mathbf{P b}$ & -0.407 & $*$ \\
$\mathbf{C d}$ & -0.179 & $*$ \\
$\mathbf{C u}$ & -0.399 & $*$ \\
\hline \multicolumn{5}{c}{$\mathrm{r}-$ critical $=0.632$} \\
& $*=$ not significant
\end{tabular}

A careful examination of the mean concentration (table 1) of the various heavy metals in both the plants and soil samples revealed that the PWS recorded the highest concentration $\left(474.14 \mathrm{mgPbkg}^{-1}\right)$ while the PWT recorded the lowest mean concentration $\left(0.02 \mathrm{mgCdkg}^{-1}\right)$. Iron tends to show higher concentration in both the plants and soil samples in the two sites. This observation supports the assertion that iron is present in a relatively higher concentration in natural biota than the other elements (Greenland and Hayes, 1981). At 0.05 level of significance, there existed no significant difference between the mean concentrations of iron in PWS and BGS. Thus the possibility of anthropogenic addition of $\mathrm{Fe}$ to the
PWS and BGS is played down. $\mathrm{Ni}, \mathrm{V}, \mathrm{Pb}$ and $\mathrm{Cu}$ were higher in PWS than BGS as shown in the t-test analysis (table 2). This trend revealed that reasonable amount of these metals might have been added to the soil through the discharge of wastes containing these heavy metals probably from pigment such as $\mathrm{PbCrO}_{4}$, $\mathrm{PbCrO}_{3}, \quad \mathrm{~Pb}(\mathrm{OH})_{2}$ or $\quad \mathrm{PbCrO} . \mathrm{Pb}(\mathrm{OH})_{2}$ and phthalocyanine $\left(\begin{array}{llll}\mathrm{C}_{32} & \mathrm{H}_{16} & \mathrm{Cu} & \mathrm{N}_{8}\end{array}\right)$ used in the manufacturing of paints.

Even though the PWS recorded very high level of $\mathrm{Pb}$ $\left(474.14 \mathrm{mgkg}^{-1}\right)$ and $\mathrm{Cu}\left(137.85 \mathrm{mgkg}^{-1}\right)$, there was no corresponding increase in the levels of these metals in the PWT. It does appear that cocoyams do not show 
the tendency to absorbed and accumulate most heavy metals. This is buttressed by the fact that at 0.05 level of significance, there was no significant correlation between the levels of heavy metals in the soil and those in the plant tubers.

In all cases, the levels of the heavy metals in the PWT were well below the upper limits documented for these metals in unpolluted plant (Vecera et al. 1999; Greenland and Hayes, 1981). Thus the PWT could not be said to be polluted by the heavy metals.

Acknowledgements: We acknowledge with immense gratitude the assistances of Dr. Etteson and P. A. Umoh for technical analysis by atomic absorption spectrophotometery; Eddy Nabuk for his advice on the statistics used; Idongesit Akpan, Esong Harry and Aniedi Peter for their tremendous contribution during the course of this work.

\section{REFERENCES}

Food and Fertilizer Technology Centre (F.F.T.C)(2000). Relationship between heavy metal concentrations in soil of Taiwan and uptake by crops. Zueng-sang Chen Dept. of Agric. Chemistry, National Taiwan University Taipei 106 Taiwan.

http//www.agnet,org/ibrary/image/tb/49t6.html.

Greenland, D J; Hayes, M H (1981). The Chemistry of Soil Processes. John Wiley and Son, New York.

Hughes, M N; Poole, R K (1995). Metals and Micro organisms. Chapman and Hall, London, New York.
Jones, M M; Johnson, D O; Netherville, J J; Wood, J L; Joesten, M D (1986). Chemistry and Society. Saunder College Publishing, U.S.A.

Martin, A J; Whitefield, P J (1983). Official Standardized Methods of Analysis. New York Society for Analytical Chemistry, New York.

Naidu, R; Oliver, D; Mconnell, S (2003). Heavy metal phytotoxicity in soil. In: Proceeding of the Fifty National Workshop on the Assessment of Site Contamination. Victoria, U.S.A., P 235.

Radojevic, M; Vladimir, N (1999). Practical Environmental Analysis. Paston Prepress Ltd., U. K.

Udosen, E D (1994). Levels of toxic metals in Telfairia occidentalis from a paint industry environment. J. Appl. Chem. Agric. Res. I (I): 34-42.

Vecera, Z; Mikuska, P; Zdrahal, Z; Docekal, B; Buckova, M; Tynova, Z; Parizek, P; Mosna, J and Marek, J (1999). Environmental Analytical Chemistry. Institute of Analytical Chemistry, Academy of Science of the Czech Republic, BMO, Veveri 97. 